\title{
Discussion on the Development Direction of Modern Clothing
}

\author{
Xiulian Wang \\ Jiangxi Institute of Fashion Technology \\ Nanchang, Jiangxi, China 330201
}

\begin{abstract}
Human's production and life are inseparable from clothes, food, accommodation, travel, consumption and other activities. Clothing art, as a symbol of the development of human civilization, has been thriving in deep historical and cultural river. Seen from the scroll of history, it can be found that the development of clothing has obvious regional and era characteristics. In the modern highly developed social environment, clothing art also has the characteristics of the times with the development of the times. Starting from the era characteristics of clothing, the paper has analyzed the factors, including politic direction, economic direction, national folk culture direction, and religious belief direction, directing the development of modern clothing art, and determined the design tendency of clothing art, guiding the follow-up development and change of clothing design.
\end{abstract}

Keywords-clothing art; direction; development and change

\section{INTRODUCTION}

People's daily life is inseparable from clothes, food, accommodation, travel, consumption and other activities. Clothing, as a symbol of the development of human civilization, has become an indelible symbol of the times after the baptism of years. It has strong era characteristics in the long scroll of history. The imprint of history has given clothing art with unique sense of times. Under the influence of complex historical background, the material and spiritual attributes of clothing contain politic and economic favors of the times. Either in war or peace, the language form of clothing art mostly reflected the good wishes of people in production and life. In addition, in terms of ideological level, people's ideologies were entrusted in it. It is a form to pass the language of the times. In the development of clothing, many factors together created the differences of clothing art in style, material, pattern, shape, color, and so on. As a researcher in the modern clothing art, the author made a research on the influencing factors of clothing art design. The main influencing factors include the development of local politics and economy, regional folk style, local customs and practices and religious beliefs, which are reflected in the following aspects:

\section{POLITICS, THE CORE FACTOR DIRECTING THE DEVELOPMENT OF CLOTHING}

Politics is a very important social phenomenon in human society, which affects all aspects of human life. In different historical periods, different languages and different cultures, the connotation is not the same. Politics is developing and changing constantly. As the most important material in people's daily life, modern clothing should meet the social needs of people. It is a great diplomatic means. The advantage shifting of clothing and politics is realized through political stage.

Politics is a kind of smart clothes. What politics open is a leadership and management mode, which is the brain of the country and region. The diplomacy and means and management with political meaning can reflect political characteristics. It is an external manifestation of political packaging. Here it does not mean clothing of actual meaning. It is the embodiment of a kind of means. Clothing is a wise politics. Clothing in the political context is a diplomatic means, reflecting the diplomatic strategy, etiquette and political status. In the 22ed APEC Economic Leaders' Meeting in 2014, leaders of all economic entities and their spouses gathered in Beijing, China. The meeting garment pursued "Chinese", "Rite" and "New", reflecting the concept of Chinese traditional clothing with stand collar, raglan sleeve and cardigan. Cheongsams for women were elegant and graceful. They selected top-grade Song-dynasty brocade fabric and Shuanggong silk as material and adopted exquisite patterns. With exquisite workmanship, it has a symbol of elegance and kindness. These clothes added splendor to the meeting. It has improved the international meaning of Chinese traditional clothing and China's international status, so it is a wise political diplomacy. There are many garments with political flavor in previous APEC meetings, which become the source of inspirations of designers from all over the world. Designers make design to meet people's needs in the pursuit of clothing. The negative aspect of politics also deeply affected people's life. After World War II, the clothing colors of Japanese were relatively somber. It is a reflection of their defeat in political war. So, the directional guidance of politics is the core idea for the development of clothing. By finding the correct political ideas, we will not go to the wrong direction.

\section{ECONOMY, THE IMPORTANT FACTOR DIRECTING THE DEVELOPMENT OF CLOTHING INDUSTRY}

The development of history tells us that political stability is the prerequisite for economic development and people's happiness. The author found that the development of clothing industry was inseparable from the driving power of economy. 
The guidance of economic policy can directly boost the new development of clothing. After the Second World War, world political situation was relatively stable. The world entered into a stage of economic recovery. Political stability drove the rapid development of the regional economy, especially the recovery of the Japanese economy after the war. Their textile and clothing industry has been greatly improved. One time Japan became a leading center of textile and garment in the world, even overtook the United States, and became the leader of the Asian economy and the exchange object for all countries to learn from. In the 1960s and 1970s, some Chinese people with new thinking began to go abroad to study in Japan. In the 1980s, Japanese culture industry went into thousands of families with the development of film and television. Japan's new clothing pattern became the hot pursuit of people. Japanese food culture, etiquette, clothing, building and etc. began to draw closer to Japanese characteristics; meanwhile it promoted the new trends of their domestic clothing industry and boosted the development of domestic economy.

The law of the development of world economy and trade tells us that economic development is a dynamic, mobile social phenomenon. It may not play a dominate role for a long term in the world. This law, in the late 1990s, started a new direction. With the upgrading of Korea's economic status, the economic dominance has begun to shift to the Republic of Korea. China has been affected South Korea's social trends, especially in clothing industry. With the development of Chinese economy, Korean clothing began to influence our clothing life since the late 1990s. Clothing of Korean style would draw much attention in stores. With the promotion of Korean soap opera, Korean culture further influences our life. We eat Korean food, learn Korean, travel to Korea and love Korean stars. Every move of some of us has been affected by Korean culture. Though a lot of trends influence our clothing, the distinctive Korean clothing has an important position in our heart. With the development of our economy, our featured clothing also will become a commodity that people of all countries love.

The economic development of our country also changes the direction of the clothing industry. Since we joined the WTO, we embraced the new mode of world clothing. In a certain sense it drove the upgrading and development of China's clothing industry. Our clothing industry broke away from the protective shell, and walked onto the road of survival of the fittest. It was a freshly new development trend. And then we enjoyed the takeoff of clothing economy in 2000. Jack Ma's e-commerce economy is a new direction to China's clothing industry. In the first five years of 2010s, the ecommerce has been a living treasure to the entire clothing economy. The state has promulgated many e-commerce policies and measures, to secure the development of clothing economy. The author predicts that the entire 2010s is the world of e-commerce. Through studying the clothing economy of the last thirty years, the author found that the more developed the economy is, the faster the trend of clothing economy changes.

\section{RELIGIOUS BELIEF DIRECTION}

For a long time in human history, the religious cultures of Islam, Buddhism and Christianity have affected the development of art design. Clothing is one of art forms. Religious culture has a unique aesthetic standard on clothing. With the dynamic spread of religious culture, people's belief may change at any time, which may change the direction of people's spiritual pursuit in clothing. White is a symbol of pureness and nobleness in Christian culture, so Christian brides wear white wedding dress in the wedding. Christians may hold their wedding ceremony in holy church. It is a collision of religious culture and clothing culture. The number of Christian is increasing with the preaching of foreign missionaries. Even it broke the leading position of Buddhism. The wedding clothing changed from traditional Chinese clothing into white dress and suits, so that we may see the influence of religion in clothing. Religion could direct the evolvement of clothing.

Human with belief have motivation in life. People are freer in religious belief. People don't just blindly worship religious culture, obey religious doctrine or accept it without thinking. They start to receive and know religion rationally, which gives the religious belief a sacred veil. This veil is given by believers, and it also drives believers to worship and admire religious thoughts even more. Clothing, as an important visual veil for believers, brings convenience in spreading religious thoughts and carrying out religious activities. Many religious believers have love and kindness, and they wear their specific types of clothing, which makes religion more solemn. But in order to compete for believers, many regions become war places because of religious problems. In order to reduce the influence of religious activities on regional political issues, modern people never stop researching the religious culture. For fashion designers, many of their design inspirations come from religious culture. On the one hand, religion serves clothing design. On the other hand, clothing, as one of religious carrier, provides new spread media to religion. Once clothing with religious favor is accepted and spread, it will bring changes in belief. Therefore, where there is a religious wind, there is a spring.

\section{The National Folk Culture Direction}

The difference of modern national folk culture has always been the focus of the political and economic war between regions. It has rose to an international focus issue which is concerned by the people who are yearning for national stability and unity. Since ancient times, political and economic problems have been big events influencing people's life. The racial tensions have always been thorny. Works of fashion designers express people's desire for peace and stability. Each nation has different living regions, so their habits of labor, climate, environment, language and food are also different. Their desires for production and life are also different from each other. Numerous nations have all sorts of cultures and life, and things of these regions become bearers of designers' inspiration and expression trend of thought. It is hard for us to change a nation's customs. But it can weaken their daily habits through popular fashions. Especially a wide range of international fashion trends may bring a qualitative leap to the whole nation. Many African primitive tribes start to go to civilized social activities under the guidance of modern civilization. 
In the ups and downs journey of clothing design, the extraction of clothing elements is numerous in kind and changing constantly. The national folk culture most widely affects clothing design, and it is the clothing element most difficult to be controlled. Only by deeply understanding the charm of national folk, can designers perfectly apply these elements into their works. In the clothing design field, Dior2007 spring and summer fashion show showed us unique Japanese folk culture, like kimono, sakura and geisha. Famous brands integrated national elements, which brought us a visual feast and caused a sensation in the fashion world. The wind of world fashion design was blown to Japan. Japanese elements one time became the focus of design. Later dress with blue and white porcelain element is a start for Chinese elements walking towards top-grade clothing circle. The national folk culture paved a new way for clothing design. The application of Indian elements and Korean elements has a high reputation in the international fashion field. Top-grade fashion brands guide this strong national wind.

In general, the above factors have absolute effect on the trend of clothing design. In addition, there are also many other factors, such as, the rise of modern personalized designer trend, international popular trend, environmental protection concept driven by environment problems, weather factor driven by serious damaged climate, the existence of natural disaster and so on. They all may become the wind vanes of clothing design. By the guidance of these wind vanes, combined with self characteristics, designers could create more excellent fashion works. These works may become new articles to spread knowledge and thoughts to the public. Whether they are positive thoughts or negative thoughts, they are the reflections of people's ideologies in production and life. If a region has stable politics, prosper economy, national unity, freedom and flexibility in religion, the stable life pattern may bring fashion design more cultural connotations, and stimulate the elegant activities hidden in the heart of designers. The wind of clothing design will not stop, and the wind direction is always changing. Where the wind is, there is a splendor. The wind will affect our life all the time, so the current production and life cannot be all smooth. They are always striving in dynamics. As the guide of wind vane of clothing design, we should face up to the changes in clothing design and reasonably use our design concepts to serve our dynamic life.

\section{REFERENCES}

[1] Li Zhaodi. Analysis of Political Elements of Clothing in Modern Times. Knowledge Economy, Jan. 1, 2010.

[2] Coolest Ethnic Trend: APEC Leaders' Garments. China Daily, Nov. 11, 2014. Http://edu.sina.com.cn/en/2014-11-11/134483472.shtml.

[3] Xie Fei. Long-standing, Blending, Challenging and Hope - Close Relationship of Clothing and Politics, Economy and Culture. Popular Literature and Art (Theory), Dec. 25, 2008.

[4] Gao Yuemei. Fashion Design in View of Nationalization. Journal of Luohe Vocational Technology College. Jul. 15, 2013.

[5] Sun Yang. Popular Clothing Culture under the Influence of Religious Culture. Journal of Nanning College for Vocational Technology, Jan. 22, 2014. 